\title{
Application of Rasa Theory in James Joyce's a Portrait of the Artist as a Young Man
}

\author{
Madhurantika Sunil \\ B. A. Student \\ Banasthali Vidyapith, Rajasthan, India
}

\section{ABSTRACT}

The synchronic and diachronic study of literature explicate that literature is essentially about life and emotions thus it has timeless appeal meaning thereby that there is something in a literary work that transcends time and space. Readers of different countries, culture, religions, ideologies, passions and prejudices do appreciate and relish literature of altogether a different place as it provides aesthetic enjoyment to them. A close conspicuous analysis of the available literature may expound the fact that the most fascinating area of intersection between Indian and Western literature is to be found in the realm of poetics and aesthetics. James joyce's A Portrait of the Artist as a Young Manis an example of German philosophy of Bildungsroman which deals with the formation of an artist, it traces the journey of Being, Becoming and Unbecoming of an individual, wherein an individual passes through the socio-pragmatic as well as aesthetico-spiritual realm of realities. In the conduit of aforementioned realities, an individual passes through a number of emotions, sentiments and feelings which in turn shape the epistemic texture of the character. The problem that confronts a critic is to find out how in a work of art, an emotion is depicted, suggested and how it is finally communicated to the reader. In the realm of Indian aesthetics, the key to any analysis of aesthetic transformation is the theory of Rasa. The Rasa Theory essentially deals with various kinds of emotions and how they are depicted, inferred and transmitted through a work of art. Thus, the present paper shall take into account philosophical underpinnings of Rasa Theory in order to analyze the given novel. Keywords: Indian aesthetics, Rasa theory, Bildungsroman.

Keywords: Indian aesthetics, Rasa theory, Bildungsroman

\section{INTRODUCTION}

If literature is communication of a special kind, language is the means of that communication. The language of literature is emotive and it has a feeling of content. It has a universal and timeless appeal that connects readers of different countries, cultures, religion, ideologies, passions and prejudices to appreciate literature of altogether a different place as it provides aesthetic enjoyment to them. Aesthetics or The Theory of Beauty in art and literature has been one of the early pursuits of human mind. The idea of beauty naturally brings in the idea of beauty and sublime. A thing of beauty is not only a joy forever, but it is an invitation to explore the reasons for that joy.

The most fascinating area of intersection between Indian and Western literatures, can be said to be found in the realm of poetics and aesthetics. Indian poetics is nothing but Sanskrit poetics which is an immortal encyclopedia of the theories and doctrines about poetry and drama. The development of Sanskrit poetics has been traced through its fairly long and varied course of history, which covers an extensive literature of more than one and half millennium. Sanskrit literature, where writings of a philosophical and speculative nature are bound, has been a fertile field in which many books have been written to enlighten the views of the readers on the nature and scope of poetry and on the nature of poetic delight.

The Indian poetics is evolved out of the dramaturgy and the oldest existing work on Indian poetics is the Natyasatra by Bharatmuni. The Rasa siddhanta occupies a prestigious place among the schools of Indian poetics and Bharatmuni is acknowledged to be the first exponent of Rasa theory which he has systematically set forth in his treatise Natayasastra. 
The Indian view of art may be said to be in the aesthetic conception of rasa.

The word Rasa is the simplest and at the same time the most bewildering expression in the Sanskrit Language. The word may convey different meanings in different contexts, but its essential core remains unaltered. "The word's meanings have been associated with a botanical substance, a sensory experience, an ontological, an aesthetic delight, a transcending otherworldly experience"(Buchta and Schweig: 2012, 623) Rasa literally means taste, relish, sentiment, aesthetic emotion etcetera. The Theory of Rasa essentially deals with the various kinds of emotions, how they are depicted, inferred and transferred through a work of art, it holds that finally literature is about life and its emotions. The strength of this theory lies in that it deals with what is common to all mankind at all times-emotions. It is a theory which is considerate of the entire literary process from its very conception in the mind of the artist to its final perception in the heart of the perceiver or reader.

It is a subtle state, requiring the pervasive influence of several different kinds of emotions and a host of feelings into fusion before it may be evoked. The Indian writers on poetics classified emotions into two categories i.e. lasting and incidental or transitory. There are eight lasting emotions which are (1) Rati( "love" ) (2) Hasa ("laughter") (3) Soka ("sorrow") ( 4) Krodha( "anger" ) (5) Utsaha( "high-spiritdness") (6) Bhaya ("fear") (7) Vismaya ("astonishment" ) (8) Jugupsa( "disgust" )(Tiwary:1984, SN"7). Abhinavagupta has dealt with each of them elaborately in his text Abhinavaharati and discussed them in the context of Purushartha of life and bring forwards the idea of Sama,quietude or the calm mental stage of sage which is directly related to the highest end of life, salvation, be developed into a pleasurable rasa, called Santa.

Of the incidental emotions they are as many as thirtythree in number: Despondency, Weakness, Apprehension, Envy, Intoxication, Joy, Agitation, Stupor, Arrogance, Despair, Longing , Sleep, Epilepsy, Dreaming, Cruelty, Awakening, Indignation, Dissimulation, Assurance, Sickness, Insanity, Death, Fright and deliberation etcetera(Tiwary:1984, 10).

The Rasas can be enumerated corresponding to their emotions as the emotion of love and the transitory feelings longing or anxiety, insanity, fever, stupor, death are bound up with the Sringara or the Erotic Rasa. The high-spiritedness and the incidental feelings like assurance, contentment, arrogance and joy use the signs of the Vira or Heroic Rasa. Anger and the attendant feelings if indignation, intoxication, recollection, inconstancy, envy, cruelty, and agitation occur with the Raudra Rasa or the Rasa of fury. Mirth with its accompanying states of indolence, weariness, weakness and stupor may arouse the Hasya Rasa. Astonishment and the feelings of Joy, agitation, distraction and fright provoke the Adbhuta Rasa or the Rasa of wonder. The emotion of sorrow is conducive to the production of Karuna Rasa or the Rasa of pathos. Disgust and the ephemeral feelings of agitation, sickness provoke the Bibhasta Rasa or the Rasa of indignation. The emotion of fear produces the Bhayanaka Rasa or the Rasa of terror.

Bhatta Lollata, Bhttanayaka, Sankuka, Mammata, Visvanatha, Abhinavagupta and many other critics have been there who have tried to write a commentary on the rasa theory of Bharata, but the interpretation by Abhinavagupta has been accepted by almost the whole intellectual and aesthetic tradition in India. In his well-known exposition, called Abhinavabharati of the Natyasastra, he has delineated his concept of Rasanubhuti. He predicates that only a person, endowed with a heart with keen faculty of perception is authorized to appreciate rasa. He gives the term Sahridaya to such a person as R.S. Tiwary in his book A Critical Approach to Classical Indian Poetics opines that, "Sensitive readers are people who have the capacity of identifying with matter under description in poetry because the mirror of their heart has become clear(or polished) due to their repeated reading and contemplation of poetry"(Tiwary:1984, 26).

Abhinavagupta's unique and supreme contribution to the elucidation of Rasanbhuti consists in his enunciation that the emotions reside in the Samajika's soul in the shape of vasnas(instincts) or Samskaras, by reason of their being transmitted and inherited by us from birth to birth. He states that the relish of Rasa altogether novel and unique is a mental function in which the Sahridayas taste the Sthayi experiencing loneliness, resulting from a contact with the Vasnas of pleasure and pain. Thus the Sthayis are the innate instincts which characterize the living being from birth. Everyone seeks pleasure, ridicules other on accounts of pride, is pained when separated from the desired objects, is angry at the causes of such 
separation and wishes to abandon many things. These mental states have their traces in every human being, only some have them to a greater extent while others have them to a smaller extent. These Sthayis existing inherently but latently in the soul became felt and experienced under the impact of the dramatic representation or the poet's delineation. Rasa then, is simply the enjoyment of one's own nature by consciousness. This experience of self-realization leads to a blissful stage or Ananda and rasa experience is nothing but this Ananda. For Abhinavagupta, rasa is alaukika in the sense that experience of rasa, as distinct from ordinary emotional experiences, requires of the audience process of abstracting and generalizing emotional experience. Abhinavagupta makes a pertinent remark and says that "rasa is the transcendental delightful perception of one's own nature tinged with the predominant feeling excited with the dramatic display"(Mishra: 1979)

James Joyce's A Portrait of the Artist as a Young Man(1916) is a classic example of Bildungsroman which deals with the formation of an artist, it traces the phenomenon of Being, Becoming and Unbecoming of an individual, wherein an individual passes through the socio-pragmatic dimension of reality which is constituted by socio-economic, cultural, political, historical, religious and linguistic realities to Aesthetico-spiritual dimension of reality which is constituted of metaphysical aspects. "The lexical existence of Bildungsroman is traced in its genesis in German aesthetics and literary vocabulary and ideology, and it resists a definite translation or glossing. It is generally translated and used as apprenticeship novel, novel of education, autobiographical novel, coming of age novel, etcetera, however it explores and divulges the early years of a character's life and it further traces the development of character's emotional and spiritual life."(Mishra: 2012, 32)

The novel portrays the story of Stephen Dedalus from his early childhood wherein the process of interpellation and subjectivization in the epistemic reality by the invisible hands of ISAs and RSAs which in turn shape his development of self to the spiritual awakening wherein he realizes the futility of materialistic world and finds himself in the world of art and aesthetics. "The odyssey of Stephen's life from 'once upon a time and very good time(1)to ...'the smithy of my soul the uncreated conscience of my race'(288) makes him to cover all wanton ways of life which is fallacious in nature. He begins his journey from a tabula rasa state of mind and finally ends with a realization that he has been constructed and subjectivized by the confounding and surreptitious elements of nationality, language and religion of which he wants to get rid of, as he says" you talk to me of nationality, language and religion. I shall try to fly by those nets"(231).Stephen makes an attempt to attain meaning in life by making a gradual yet a very significant move into the world of aesthetics and art. He does this remarkable movement into the world of art and aesthetics because it provides one with both the form and content, the form is the beauty and the content is the truth of the beauty."(Mishra: 2012, 39)

The life of the protagonist of the novel Stephen Dedalus is characterized by a number of major and minor events which in turn shape the development of the character leading up to the realization of the state of bliss. Emotions are the chief constituents of a literary experiences. They play an important role in the realization of Rasa. The whole life of the protagonist constituted by experiences culminates into different emotions thus resulting into different Rasas. One of the instances that we see in the novel, is when Stephen has been left by his parents in his school, and mothers has tears in his eyes, separation is there, thus we could see Karuna Rasa, another instance that we see is when Stephen goes to the rector in order to complain about the injustice done to him by a teacher, which is a heroic stage in his life, it is here for the first time that he takes the stand for himself for the first time, thus presenting the Vira Rasa at the moment. Further, we see that he has been bullied by the senior boys of the school, who are rough in attitude and he feels afraid of them thus giving us the portrayal of Bhayanaka Rasa. Furthermore, we see his two love affairs or sexual encounters, one debasing, and another exalting, where he is experiencing Sringara Rasa. For the realization of the Santa Rasa the basic feeling that has to be stabilized is that of spiritual calm. This is an affection caused by one's true knowledge, of ones's own pure infinite universal self. This is what we see at the end of the novel, where the protagonist articulates, "Welcome, $\mathrm{O}$ life! I go to encounter for the millionth time the reality of experience and to forge in the smithy of my soul the uncreated conscience of my race"(Joyce:1916, 288). 
In nutshell, we could see that how the protagonist has experienced different rasas. Simultaneously, we see that Rasa theory has a universal criterion to appreciate any creative literature, and how both Indian and Western literatures shares an area of intersection in the realm of poetics and aesthetics. To conclude, literature represents life and its emotions.

\section{REFERENCES}

1. Attridge, Derek Ed. (2002). The Cambridge Companion to James Joyce. Cambridge: Cambridge University Press.

2. Buchta, David and Schweig Graham M.(2012). Rasa Theory: Brills Encyclopedia of Hinduism, 623-629.www.academia.edu.

3. Bolt, Sydney (2016). A Preface to Joyce. New York: Routledge.

4. Bhatia, Dr. Namita(2016). The 'Rasa' Theory and the Concept of the 'Sublime': A Universal Approach to Bharatmuni and Longinus. IOSR Journal of Humanities and SocialSciences, 21(10), 10-12.www.iosrjournals.org.

5. Chaitanya Krishna(1918). Sanskrit Poetics: A Critical and Comparative Study. Bombay: Asia Publishing House.

6. Choudhary, Pravas Jivan (1965). The Theory of Rasa. The Journal of Aesthetics and Art Criticism, 24(1), 145-149. https://www.jstor.org/stable/428204.

7. Joyce, James (1916). A Portrait of the Artist as a Young Man. Harmondsworth: Penguin.

8. Masson, J.L. and Patwardhan, M.V. (1969). Santarasa and Abhinavagupta's Philosophy of Aesthetics. Poona: Bhandarkar Oriental Research Institute.
9. Mishra, Binod and Mishra, Veerendra Kumar (2015). Spiritual and Aesthetic Quest in James Joyce's A Portrait of the Artist as a Young Man. The Critique, 4, 19-23. https;//www.researchgate.net/profile/Binod_Mishr a.

10. Mishra, Shrikrishna.(1979). Coleridge and Abhinavagupta: Comparative Study of Poetry in the East and the West. Calcutta: Pradeep Kumar Hasna.

11. Mishra, Veerendra Kumar (2014) Modern Novels and Poetics of Self: Reading Modernist Bildungsromane. New Delhi: Authors Press.

12. Mishra, Veerendra Kumar and Mishra, Binod (2012). Aesthetic Experience and Epiphany in Bildungsroman: A Reading of James Joyce's A Portrait of the Artist as a Young Man. The Atlantic Critical Review, 11. 31-44. https://www.researchgate.net/profile/veerendra_M ishra.

13. Patnaik, Priyadarshi (2004). Rasa in Aesthetics: An Application of Rasa Theory to Modern Western Literature. New Delhi: D.K. Printworld (P) Ltd.

14. Sankaran, A. (1973). Some Aspects of Literary Criticism in Sanskrit. New Delhi: Oriental Books Reprint.

15. Sastri,P.S. (1989) Indian Theory of Aesthetic. New Delhi: Bhartiya Vidya Prakashan.

16. Thampi, G.B. Mohan(1965). "Rasa" as Aesthetic Experience. The Journal of Aesthetics and Art Criticism, 24(1), 145-149. https://www.jstor.org/stable/428249.

17. Tiwary, R.S. (1984). A Critical Approach to Classical Indian Poetics. Varanasi: Choukhmaba Orientalia. 